\section{Fra Støv til Guld}

af seniorforsker, dr.phil. Karen Skovgaard-Petersen, Det Kongelige Bibliotek

$\mathrm{F}$ ra støv til guld handler om de små bøger, som folk læste i massevis for nogle århundreder siden: nyhedstidender, romaner, skillingsviser, håndbøger, skolebøger m.m. Det var små og billige brug-og-smidvæk-tryksager, som man ikke fandt værd at gemme - og derfor er de i dag store sjældenheder.

Men de giver et os et blik ind $\mathrm{i}$ hverdagsliv og forestillingsverden hos det store flertal af mennesker, der ellers ikke kom til orde i 15-, 16-, og 1700-tallet. Og tilsammen fortæller de hvordan bogen og det trykte medie blev en del af hverdagen i de første århundreder efter trykkekunstens opfindelse, ikke bare for de lærde og uddannede, men også for den menige mand og hans kone.

Jeg vil give jer en hastig rundtur $\mathrm{i}$ Montana-salen omkring den store runde montre som rummer de små og tilsyneladende uanselige tryksager.

Trykkekunstens udbredelse betød en revolution i nyhedsformidlingen. Der blev fra 1500-tallet og frem trykt mængder af nyhedsblade, som fortalte om en enkelt begivenhed, altid af sensationel karakter. Nogle af dem var illustrerede, som 'Aftegning Om dend Store Hvalfisk, som er død opdreven ved det Gammel-Amager den 17
Juli 1725. Kiøbenhavn, findes tilkiøbs hos Christian Thielo'.

Nyhedsformidlingen foregik også i form af skillingsviser der blev falbudt på gader og stræder af 'visekællinger', især i 1700- og 1800-tallet. Med en sensationslyst der ikke står tilbage for vore dages formiddagsblade, fortalte de med forkærlighed om mord, barnerov, utroskab og alskens ulykker. F.eks. en vise om hvordan mestertyven Peder Mikkelsen - en tilbagevendende skikkelse i flere viser - 'morer sig med at synge en Vugge-Vise for sin lille Datter Judithe, som han nyelig har lagt sig til i Stokhuset. Udgivet af S. Laugier, Student. Kjøbenhavn 1804.

Verden blev større i disse århundreder, hvor europæerne koloniserede stadig nye områder, og det satte sig spor på bogmarkedet hjemme i Europa. Store værker om de fremmede verdensdele, rigt illustreret med kobberstik, udkom side om side med mere beskedent udstyrede rejseberetninger. I de ældste trykte bøger lever gamle forestillinger om mærkværdige væsener i de yderste kanter af verden i bedste velgående. Hos Lucidarius, en slags encyclopædi med

\section{Tale ved åbningen af udstillingen Fra støv til guld $i$ Dronningesalen 10. november 2006. Udstillingsäbningen markerede samtidig åbningen af Montanasalen.} rødder tilbage i 1100 tallet, et meget tidligt dansk tryk fra ca. 1510 , hører vi om forskellige bizarre folkeslag - nogle har f.eks. en fod så bred at den kan beskytte dem mod regn og sne. Disse væsener kunne man også møde senere i 1500-tallet, bl.a. i Sebastian Münsters store verdensbeskrivelse. Verdensdelene, allegorisk afbildet, optræder $i$ en etbladstryk fra den anden ende af vores tidsperiode, fra tiden omkring 1800 , hvor man om Afrika kan læse at 'vel har den guld og sølv samt hist og her skjøn Frugt, / men Videnskab og Kunst ei bliver meget brugt'. 
Mærkværdige folkeslag, såsom de storfodede mennsker, hørte som sagt til i verdens fjerneste egne. Men underlige hændelser kunne finde sted hvorsomhelst - også i Sokkelund herred, Gladsaxe sogn, hvor en pige i 1625 blev født med øjensynligt et underligt forvokset hoved. Et lille nyhedstidende tolker det som et varsel om Guds snarlige straf over alle dem som 'holde hart ved deres ny noder, høje toppe og forargelige klædedragt' - medmindre de nu skynder sig at gøre bod og angre. Og selv om den slags forklaringer efterhånden tabte terræn, varede fascinationen af det mærkværdige og monstrøse ved. En omrejsende kæmpe, Bernhard Gigli fra Trento, hvis besøg i Danmark, og fremvisning for kongen, blev i 1765 foreviget og mangfoldiggjort i et etbladstryk.

Menneskekroppen var emnet for en række lægebøger på dansk, beregnet for den menige mand. Vi viser nogle eksempler i udstilllingen - og dertil har vi føjet nogle af samtidens store illustrerede, udenlandske værker på latin og tysk (som jo altså er paradoksalt nok, bevaret i betydelig flere eksemplarer end de små dansksprogede tryk).

Nogle af dem er udpræget videnskabelige, men et enkelt er netop beregnet for et bredere publikum. Det har den, for et anatomisk værk meget passende titel, Kend dig selv. Det vakte opsigt ved sine pædagogiske afbildninger af menneskekroppen: Ved at løfte på flapper kan man kigge inden for - på musker, knogler, blodsystem m.m.

Lægebøger kan vi nikke genkendende til. Mere fremmedartede for en moderne betragtning er tidens mange vejledning i kunsten at dø den rette død. Dødedansen var en fælleseuropæisk genre, som også er repræsenteret i Danmark. Døden er rå og brutal og byder alle op til dans, uden forskel på høj og lav.

Livets korthed og den evige salig- hed er emnet for opbyggelig læsning af mange slags - også i vise-form fra det tidlige 1700-tal. Opbyggelig læsning var velset, ja direkte støttet af myndighederne. Det var netop ønsket, fra officiel side, om at så mange som muligt skulle have direkte adgang til Guds skrevne ord, der lå bag bestræbelserne for at udbrede læsefærdighederne i befolkningen. Der blev udgivet mængder af abc'er og andre skolebøger, især i 1600-tallet, men dem har tiden været hård ved. Af Abc'er er det kun resterne af et par stykkerne vi har bevaret i dag.

Bogen holdt sit indtog i hverdagslivet i løbet af 16- og 1700-tallet - også i den forstand at man vænnede sig til at hente hjælp til daglige, praktiske gøremål i de trykte bøger. Der udkom bøger på dansk, for den 'menige mand', med anvisninger i dagligdagens sysler, såsom madlavning og biavl.

Også forskellige former for underholdende tidsfordriv gav bøgerne instruktioner i. Fra sidste del af 1700-tallet er der bevaret gådebøger og spillebøger - om gnav, skak, billard, whist m.m. At tallotteri var populært i denne periode, vidner flere viser og etbladstryk om - med en løftet pegefinger: Et skillingsvisetryk fortæller med skadefryd, og til skræk og advarsel, om en grådig skoflikker og hans kone der mente at have vundet den store gevinst, men endte med at udsættes 'for hele Byens Skoggerlatter'.

Underholdningslitteratur, romaner - de såkaldte folkebøger - blev genudgivet igen og igen. Men også de er elendigt overleveret. Historierne om Uglspil og Faust har formodentlig forladt trykpressen i tusindvis af eksemplarer i 1500-1600-tallet, uden at have efterladt sig spor i dag. Historien om Uglspil, en slags omvandrende nar der driver gæk med høj og lav, var populær 


\section{c⿻一𠃋十}

fen, fom benterfer en Nogel, et egentlig Den, fom foranoret Tonernes Nawn paa Sy-
ftema.

If Dente bosfolgende Claveer-Tabel, fom feal foreftilfe et Claveer- Sirtbe = Brat

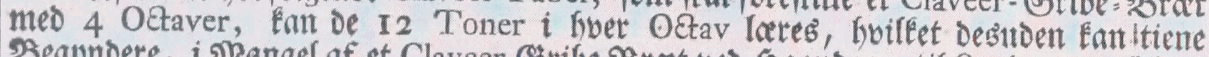

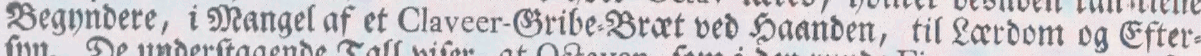
(i)n. De underftanende Sall bifer, at Octaven, fom $i$ ben tunde Figur er cepareret fia Primo-Tonen, bliver bet ifin Droen ved 8. I. under boer $\mathfrak{B}$ eglndelfe:Tone foreftiffet.

\section{Claveret med 12 Toner i buer Octav eller 49 Tafter.}

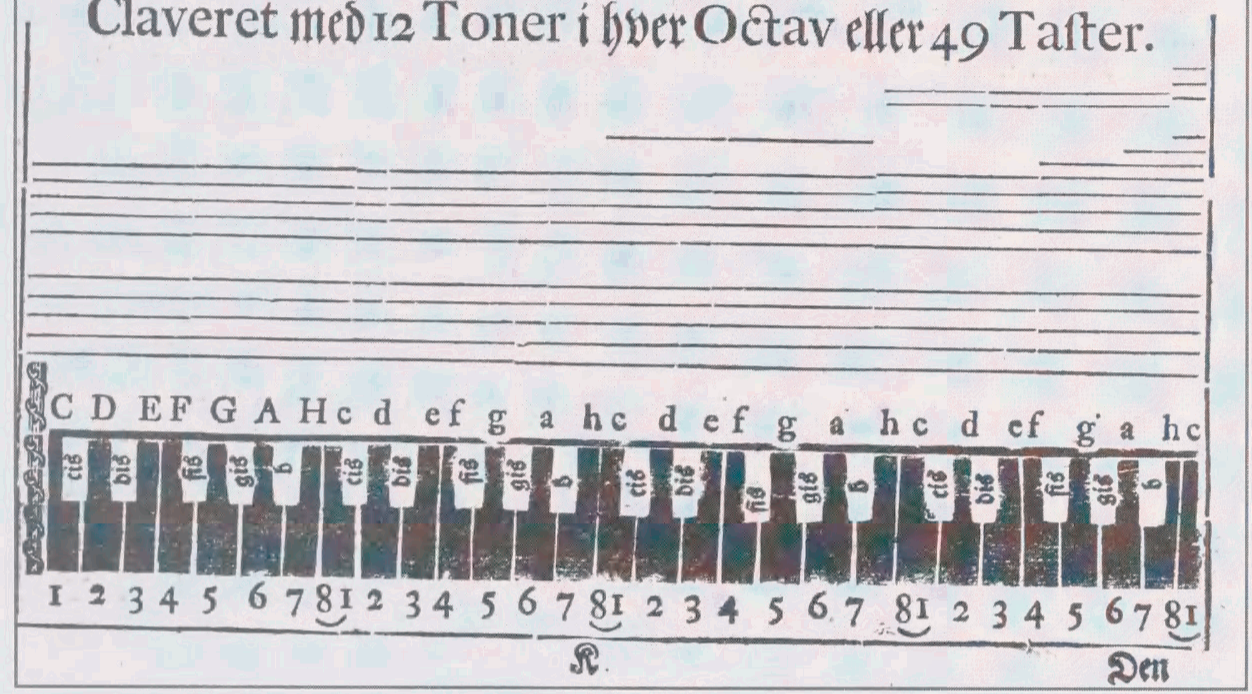

Fra Lorents Nicolaj Berg: Den første Prøve for Begyndere udi Instrumental-Kunsten. Christianssand, 1782 (Det Kongelige Bibliotek).

læsning helt fra 1500-tallets midte og ind i 1800-tallet (ikke bare i Danmark) - men den var ikke velset af myndighederne og andre vogtere af moralen, subversiv og lejlighedsvis stødende mod den pæne smag som den var. Ikke desto mindre har den været en glimrende indtægtskilde for bogproducenterne-og konflikten mellem deres profit og hensynet til moralen og den gode smag går som en rød tråd gennem disse århundreders folkelige bogkultur. Forlæggeren F. C. Pelt var en af dem der spandt guld på små underholdende historier som 'Den svenske Robinson' - en fantastisk beretning om en svensk adelsmænds færd rundt i verden, med lettere vovede indslag om hans amou- røse eventyr. Pelt så sig nødsaget til at forsvare sine udgivelser af den slags bøger:

'Det hedder, at vi Forlæggere formedelst slette Bøgers Oplag fordærve den almindelige Smag. Men udentvivl er Livet mere værd end en god Smag. Synd at forlange, at vi skulde være sådanne Martyrer af god Smag, at vi derover gav Næringen op og gjorde Bekostning paa Skrifter, som Ingen uden et lidet Antal af Skjønsomme læste.'

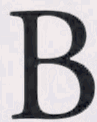
øger blev læst - og de blev læst højt. Rasmus Nyerup, der i 1816 skil drede de gamle folkebøger - i bogen Almindelig Morskabslasning i Danmark og 


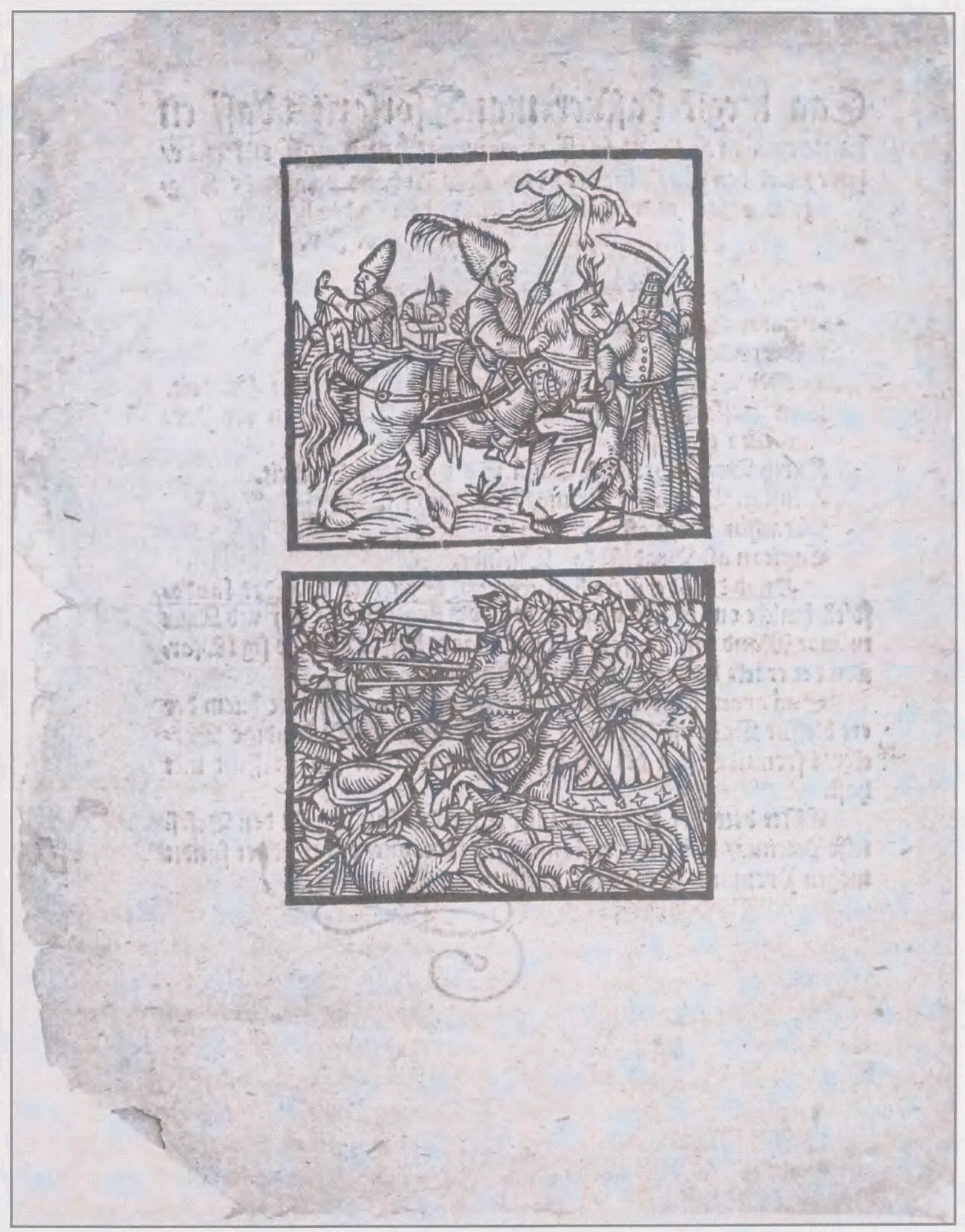

Nyhedsblad fra 1593 med en beretning om de kristnes nylige sejr over tyrkerne. Trykt af Mads Vingaard $i$ Kobenhavn (Det Kongelige Bibliotek). 
Norge igjennem Aarhund-reder-giver et glimt af de fælles læsestunder på landet i generationen før ham selv: 'Den (historien om Holger Danske) findes næsten i hveranden Bondehytte, eller fandtes idetmindste endnu for en 40 Aar siden, og fore-læstes hyppig de hellige Aftener, ved Kartegilder, humleplukken, og slige Samqvem'. Ikke alle mennesker kunne læse - selv ikke i sidste halvdel af 1700-tallet. Men gennem højtlæsning og genfortælling fik en langt større kreds af mennesker adgang til bogens verden.

Og det er den historie, hvordan bogen blev en del af den almindelige hverdag, vi prøver at fortælle, i små og spredte glimt i udstillingen. Nu talte jeg før så prosaisk om den store runde montre. Den er i Peter Holst Henckels hænder blevet forvandlet til en bog vi åbner og blader i. Jeg vil ikke røbe mere om Peters både smukke og overraskende og idesprudlende design, men blot takke Peter for et fint og inspirerende samar- bejde - og så opfordre jer alle til om lidt at gå op og nyde rummet, åbne bogen.

Det er også Peter der har designet den lille arkivæske, som viser sig ikke at gemme en gammel arkivpakke men en ny bog, som vi udgiver i forbindelse med udstillingen. Den indeholder fire fine artikler som i høj grad har givet stof og ideer til udstillingen, forfattet af Charlotte Appel, Henrik Horstbøll, Jens Henrik Koudal og Michael Harbsmeier.

Mange andre mennesker har knoklet intenst og ihærdigt med både rummet og udstillingen. Det har været en stor, og af og til temmelig hektisk, oplevelse at være en del af dette team. Jeg tror vi alle har glædet os dag for dag i den sidste tid hvor Peters visioner for rummet gradvist er blevet til virkelighed, og de små nyhedsblade, lægebøger, folkebøger osv. - de små brugog-smid-væk-tryk er kommet til ære og værdighed i den nye Montanasal.

I forbindelse med udstillingen udkom bogen Fra stov til guld. Brugsboger og skillingstryk fra Det Kongelige Bibliotek. Kr.119,- 